\title{
PENGARUH UKURAN PERUSAHAAN, PROFITABILITAS, DAN LEVERAGE TERHADAP PENETAPAN TINGKAT DISKONTO DALAM ADOPSI METODE EKUITAS
}

\author{
Mei K. Abdullah \\ IAIN Sultan Amai Gorontalo \\ Email : meiabdullah@iaingorontalo.ac.id
}

\begin{abstract}
This study aims to obtain empirical evidence of the effect of firm size, profitability, and leverage on the determination of the discount rate when the adoption of equity method. Firm size is measured by using natural logarithm of total company asset, Profitability is measured by Return on Equity (ROE), and Leverage is measured by Debt to Equity (DER). The discount rate is measured by the discount rate set by the company. The population in this study is a company listed Indonesia Stock Exchange during the year 2015-2016. The research data is obtained from the company's financial report on Bursa Effek Indonesia during the year 2015-2016. Pursuant to purposive sampling method, the sample obtained as many as 208 companies during 2015-2016. The hypothesis in this study was tested using multiple regression. The result of firm size analysis has negatif and not significant influence to the determination of discount rate and profitability and leverage analysis has positif and significant effect on the determination of discount rate at the time of adoption of equity method.
\end{abstract}

Keywords: Firm Size; Profitability; Leverage, Discount Rate

\begin{abstract}
Abstrak
Penelitian ini bertujuan untuk memperoleh bukti empiris tentang pengaruh ukuran perusahaan, profitabilitas, dan leverage terhadap penetapan tingkat diskonto ketika adopsi metode ekuitas. Ukuran perusahaan diukur dengan menggunakan natural logaritma dari total aset perusahaan, Profitabilitas diukur dengan menggunakan Return on Equity (ROE), dan Leverage diukur dengan Debt to Equity (DER). Tingkat diskonto diukur dengan tingkat diskonto yang ditetapkan oleh perusahaan. Populasi dalam penelitian ini adalah perusahaan yang terdaftar Bursa Efek Indonesia selama tahun 2015-2016. Data penelitian diperoleh dari laporan keuangan perusahaan pada Bursa Efek Indonesia selama tahun 20152016. Berdasarkan metode purposive sampling, sampel yang diperoleh sebanyak 208 perusahaan selama 2015-2016. Hipotesis dalam penelitian ini diuji menggunakan regresi berganda. Hasil analisis ukuran perusahaan berpengaruh negatif dan tidak signifikan terhadap penetapan tingkat diskonto dan analisis
\end{abstract}

* Corresponding author's e-mail: meiabdullah@iaingorontalo.ac.id

http://openjournal.unpam.ac.id/index.php/JABI 
profitabilitas dan leverage berpengaruh positif dan signifikan terhadap penetapan tingkat diskonto pada saat adopsi metode ekuitas.

Kata kunci : Ukuran Perusahaan; Profitabilitas; Leverage; Tingkat Diskonto

\section{PENDAHULUAN}

Perusahaan memiliki kewajiban untuk memberikan imbalan pascakerja bagi karyawannya sebagai wujud kepedulian perusahaan bagi kesejahteraan karyawan. Kewajiban imbalan pascakerja adalah kewajiban perusahaan di masa depan namun harus diakui saat ini, oleh karena itu perusahaan harus mengestimasi berapa nilai sekarang (present value) kewajiban pasca kerja dengan menggunakan asumsi aktuarial. Menurut PSAK 24 (revisi 2013) asumsi aktuarial terdiri atas asumsi demografik dan asumsi keuangan. Asumsi demografik berhubungan dengan mortalitas, masuk dan keluarnya pekerja, tingkat kecacatan, pensiun dini karyawan, proporsi tanggungan dan jumlah klaim atas manfaat kesehatan. Asumsi keuangan berhubungan dengan tingkat diskonto, level imbalan, biaya kesehatan dan pajak terutang atas iuran yang terkait.

Tingkat diskonto yang digunakan untuk menghitung total biaya imbalan pascakerja masa depan ditetapkan perusahaan dengan mengacu pada imbal hasil pasar atas bunga obligasi korporasi berkualitas tinggi. Pada sebuah negara yang tidak memiliki sebuah pasar aktif dan stabil, maka digunakan imbal hasil pasar atas bunga obligasi pemerintah (PSAK 24, revisi 2013). Dalam kondisi tidak ada pasar obligasi korporasi dan obligasi pemerintah, entitas dapat menerapkan tingkat diskonto rata-rata tertimbang tunggal atau dengan menghitung sendiri tingkat diskonto pasar kini, selama masih berada dalam rentang kurva imbal hasil.

Godwin (1996) menjelaskan bahwa tingkat diskonto menjadi sarana manajemen laba bagi perusahaan. Perusahaan meningkatkan tingkat diskonto ketika menghadapi penurunan laba, pembatasan dividen dan menghadapi ketatnya perjanjian hutang. Parker, dkk (2016) dalam penelitiannya menjelaskan bahwa manajer perusahaan baik pada perusahaan yang sehat secara finansial maupun yang tidak sehat secara finansial menggunakan tingkat diskonto untuk melakukan manajemen laba. Asthana (1999) menjelaskan bahwa perusahaan menggunakan tingkat diskonto yang rendah ketika dana pensiun yang tersedia lebih tinggi dari kewajiban yang harus dibayarkan (overfunding). Sebaliknya, perusahaan menggunakan tingkat diskonto yang lebih tinggi ketika berada dalam posisi underfunding. Dengan demikian tingkat diskonto dapat digunakan perusahaan untuk meningkatkan maupun menurunkan laba perusahaan.

Perusahaan dengan karakteristik yang berbeda, memiliki tujuan laba yang berbeda. Perusahaan besar misalnya lebih condong pada tujuan menurunkan laba dibanding perusahaan kecil, karena perusahaan besar sensitif pada aspek politik dan cenderung menjadi perhatian publik sehingga besar kecilnya laba akan diterjemahkan berbeda oleh berbagai pihak. Menurut Morais (2010) perusahaan besar cenderung mengakui keuntungan aktuarial dengan menggunakan metode 
koridor sebelum diwajibkannya penggunaan metode ekuitas. Hal ini dilakukan perusahaan untuk memanajamen laba agar terlihat rendah. Setelah adanya kewajiban untuk mengadopsi metode ekuitas, perusahaan memiliki saldo keuntungan aktuarial yang harus segera diakui keseluruhannya. Hal ini tidak menguntungkan bagi perusahaan besar yang menginginkan penurunan laba, oleh sebab itu perusahaan memiliki insentif untuk menurunkan nilai keuntungan aktuarial, menihilkannya, atau menciptakan kerugian aktuarial dengan cara meningkatkan nilai kewajiban pascakerja. Perusahaan besar dapat meningkatkan nilai kewajiban pascakerja untuk menurunkan saldo keuntungan aktuarial dengan menggunakan tingkat diskonto yang lebih rendah.

Sebelum metode ekuitas diwajibkan, perusahaan dengan profitabilitas tinggi cenderung menggunakan metode koridor ketika memiliki saldo kerugian aktuarial (Morais, 2010). Resiko yang dihadapi oleh perusahaan yang sebelumnya menggunakan metode koridor adalah adanya saldo kerugian aktuarial yang harus segera diakui pada saat periode adopsi metode ekuitas. Perusahaan mungkin akan menurunkan nilai kerugian aktuarial, menihilkan nilai kerugian aktuarial atau menciptakan keuntungan aktuarial sehingga pada saat adopsi metode ekuitas perusahaan tidak mengakui adanya kerugian. Perusahaan dapat menurunkan nilai kerugian aktuarial atau menciptakan keuntungan aktuarial dengan cara menurunkan nilai kewajiban pascakerja, dan kewajiban pascakerja dapat diturunkan nilainya oleh perusahaan dengan menggunakan tingkat diskonto yang lebih tinggi. Semakin tinggi nilai diskonto semakin menurun nilai kewajiban pascakerja, dan penurunan nilai kewajiban pascakerja secara bersamaan akan menurunkan beban imbalan pascakerja periode berjalan yang berdampak pada peningkatan laba perusahaan.

Perusahaan dengan leverage yang tinggi memiliki kepentingan untuk mengakui keuntungan aktuarial ketika mengadopsi metode ekuitas karena keuntungan aktuarial akan menurunkan nilai kewajiban dan meningkatkan nilai ekuitas. Apabila pada saat adopsi perusahaan memiliki kerugian aktuarial, maka nilai kerugian aktuarial akan meningkatkan nilai kewajiban dan mengurangi nilai ekuitas yang berdampak pada kenaikan nilai leverage. Kenaikan nilai leverage menunjukkan bahwa sebagian besar operasional didanai oleh hutang bukan oleh modal (ekuitas), dan hal ini tidak diinginkan oleh kreditur sebagai pemberi dana. Untuk dapat menurunkan nilai leverage, perusahaan dapat menurunkan nilai kewajiban dengan cara meningkatkan tingkat diskonto. Asthana (1999) menjelaskan bahwa perusahaan dengan hutang yang tinggi lebih cenderung menggunakan diskonto yang tinggi.

Penelitian ini hendak melihat perilaku perusahaan ketika diwajibkan menggunakan metode ekuitas dalam pengakuan seluruh kerugian/keuntungan aktuariall yang sebelumnya belum diakui pada metode koridor. Apakah perusahaan dengan karakteristik tertentu menggunakan tingkat diskonto untuk mengelola keuntungan dan kerugian aktuarial ketika diwajibkan metode ekuitas? Berdasarkan fenomena ini penelitian dilakukan ketika perusahaan diwajibkan menggunakan menggunakan metode ekuitas (2015-2016). 


\section{KERANGKA TEORITIS DAN PENGEMBANGAN HIPOTESIS}

Menurut Watts dan Zimmerman (1978) teori akuntansi positif adalah teori yang bertujuan untuk memberikan penjelasan dan memprediksikan sebuah praktikk akuntansi.

"is concerned with explaining accounting practice. it is designed to explain and predict which firm will and which firms not use particular method.... but it says nothing as to which method a firm should use."

Menurut Deegan (2004) yang dimaksud dengan "penjelasan" dalam teori positif adalah penjelasan mengapa perusahaan menggunakan salah satu metode atau praktik akuntansi, bukan memberikan anjuran mengenai bagaimana praktik akuntansi seharusnya. Sebagai contoh teori positif memberikan penjelasan tentang alasan banyak perusahaan lebih cenderung menyukai penggunaan salah satu metode persediaan dibandingkan lainnya (Januarti, 2004). Selain untuk menjelaskan alasan penggunaan salah satu metode, teori akuntansi positif juga bertujuan untuk melakukan prediksi fenomena teramati. Misalnya prediksi respon perusahaan terhadap standar akuntansi yang diusulkan dan memberikan alasan ketika perusahaan melobi standar tersebut, meskipun standar akuntansi telah dirilis. Watt \& Zimmerman (1978) merumuskan hipotesis teori akuntansi positif dalam bentuk "oportunistik" yang sering diinterpretasikan dengan hipotesis biaya politik, hipotesis rencana bonus dan hipotesis perjanjian hutang.

Tingkat diskonto yang ditetapkan perusahaan dalam menetapkan nilai kini kewajiban pascakerja diterbitkan berdasarkan imbal hasil pasar bunga obligasi korporasi berkualitas tinggi pada akhir periode pelaporan. Di negara di mana tidak terdapat pasar yang aktif dan stabil bagi obligasi tersebut, maka digunakan imbal hasil pasar atas bunga obligasi pemerintah.

Asumsi keuangan dengan dampak signifikan adalah tingkat diskonto. Tingkat diskonto tidak mencerminkan risiko aktuarial maupun risiko investasi. Selain itu, tingkat diskonto tidak mencerminkan risiko kredit yang spesifik bagi perusahaan yang ditanggung oleh kreditur perusahaan, bahkan risiko kemungkinan kondisi masa depan akan berbeda dengan tingkat diskonto yang ditetapkan sebelumnya.

Suwito dan Herawaty, 2010 menjelaskan bahwa Ukuran perusahaan adalah pengelompokkan perusahaan ke dalam beberapa kelompok, di antaranya perusahaan besar, sedang dan kecil. Skala perusahaan merupakan ukuran yang dipakai untuk mencerminkan besar kecilnya perusahaan yang didasarkan pada total aset perusahaan. Riyanto (2008) menjelaskan bahwa ukuran perusahaan dapat dukur dari jumlah equity, penjualann, atau i aset. Skala perusahaan dapat didefinisikan melalui beragam kriteria, misalnya nilai aktiva, nilai penjualan, dan jumlah karyawan (Longenecker, 2001). Menurut Prasetyantoko (2008) total aset mampu menjelaskan ukuran perusahaan, aset yang besar mencerminkan perusahaan yang besar. Profitabilitas adalah ukuran kemampuan untuk menghasilkan laba atas modal yang diinvestasikan secara keseluruhan. Profitabilitas mencerminkan posisi kompetitif perusahaan di pasar, dengan perpanjangan kualitas manajemen. Laporan laba rugi mengungkapkan sumber laba dan komponen pendapatan dan biaya. Laba dapat didistribusikan kepada 
pemegang saham atau menginvestasikannya kembali di dalam perusahaan (Robinson, 2004).

Analisis leverage digunakan untuk mengukur berapa besar dana perusahaan yang berasal dari hutang, atau seberapa besar operasional perusahaan dibiayai dengan hutang. Leverage memberikan informasi mengenai jumlah hutang perusahaan didalam struktur modal dan kecukupan laba dan arus kas untuk menutupi beban bunga dan biaya tetap lainnya (seperti pembayaran sewa). Analis biasanya berusaha untuk memahami penggunaan hutang perusahaan disebabkan oleh berbagai alasan penting, diantaranya hutang dalam struktur modal digunakan dalam penilaian risiko perusahaan (Robinson, 2004).

\section{Pengaruh Ukuran Perusahaan terhadap Tingkat Diskonto}

Salah dan Smaoui (2014) menjelaskan bahwa perusahaan besar cenderung menggunakan tingkat diskonto yang lebih rendah untuk menghindari visibilitas biaya. Demikian halnya dengan Parker, dkk (2016) juga menjelaskan bahwa ukuran perusahaan mempengaruhi tingkat diskonto secara negatif dan signifikan. Hal ini membuktikan bahwa perusahaan besar memang menggunakan tingkat diskonto yang lebih rendah untuk meningkatkan nilai kewajiban/beban imbalan pascakerja untuk menurunkan laba sebagaimana dalam hipotesis biaya politik. Semakin besar ukuran perusahaan, semakin tinggi insentifnya untuk memilih menetapkan tingkat diskonto yang tinggi untuk menurunkan kewajiban ketika mengadopsi metode ekuitas. Maka hipotesis pertama dalam penelitiann ini adalah: H1 : Ukuran Perusahaan berpengaruh negatif terhadap penetapan tingkat diskonto perusahaan ketika mengadopsi metode ekuitas

\section{Pengaruh Profitabilitas terhadap Tingkat Diskonto}

Morais (2010) menjelaskan bahwa ketika pengakuan keuntungan dan kerugian aktuarial masih diperbolehkan menggunakan berbagai metode, perusahaan dengan profitabilitas tinggi umumnya menggunakan metode ekuitas ketika mengakui adanya keuntungan aktuarial dan menggunakan metode koridor ketika mengakui kerugian aktuarial. Menurut Asthana (1999) Perusahaan dengan profitabilitas rendah cenderung menggunakan asumsi tingkat diskonto yang lebih tinggi untuk meminimalkan kontribusi, dan perusahaann dengan profitabilitas tinggi cenderung menggunakan tingkat diskonto yang lebih rendah untuk memaksimalkan kontribusi. Dengan demikian perusahaan dengan profitabilitas rendah dan memiliki kerugian aktuarialnya cenderung akan menggunakan tingkat diskonto yang lebih tinggi, sementara perusahaan dengan profitabilitas tinggi dan memiliki keuntungan aktuarial akan menggunakan tingkat diskonto yang lebih rendah. Untuk itu hipotesis kedua dalam penelitian ini:

H2: Profitabilitass perusahaann berpengaruhh terhadapp penetapan tingkatt diskonto perusahaan ketika mengadopsi metode ekuitas

\section{Pengaruh Leverage terhadap Tingkat Diskonto}

Fasshuer, dkk (2008) menyatakan bahwa kewajiban pensiun perusahaan yang memiliki saldo kerugian aktuarial mengalami peningkatan ketika perusahaan beralih dari metode koridor ke metode ekuitas. Kerugian aktuarial ketika diakui dengan menggunakan metode ekuitas akan meningkatkan nilai kewajiban imbalan 
pascakerja dan menurunkan nilai ekuitas. Dengan demikian, kerugian aktuarial bagi perusahaan dengan tingkat leverage yang tinggi justru akan menambah peningkatan leverage.

Menurut Salah dan Smaoui (2014) perusahaan dengan leverage yang tinggi menggunakan tingkat diskonto yang lebih tinggi untuk menurunkan kewajiban pensiunnya. Hal ini juga didukung oleh penelitian Asthana (1999) dan Parker, dkk (2015) yang menjelaskan bahwa semakin besar hutang perusahaan semakin tinggi kemungkinan perusahaan menetapkan tingkat diskonto yang lebih tinggi. Maka hipotesis ketiga dalam penelitian ini adalah:

H3: Leverage berpengaruh positif terhadap penetapan tingkat diskonto perusahaan ketika mengadopsi metode ekuitas.

\section{METODE RISET}

Variabel dependen yang digunakan dalam penelitian ini adalah tingkat diskonto yang digunakan perusahaan dalam mengestimasi jumlah biaya kewajiban imbalan pascakerja. Pengukuran tingkat diskonto dilakukan dengan menggunakan nilai tingkat diskonto yang digunakan perusahaan pada periode pelaporan (Salah dan Smaoui, 2014)

Variabel independen dalam penelitian ini adalah Ukuran Perusahaan, Profitabilitas dan Leverage. Riyanto (2008) menjelaskan bahwa ukuran perusahaan dapat dilihat dari aset, ekuitas, dan penjualan. Adapun Ukuran perusahaan yang digunakan dalam penelitian ini adalah nilai aset sebagaimana dalam penelitian Parker, dkk (2016). Kemampuan perusahaan dalam mendapatkan laba dengan melakukan penjualan, menggunakan aset atau modal sendiri disebut dengan profitabilitas. Ukuran Profitabilitas pada penelitian ini menggunakan Return on equity seperti penelitian Morais (2010) yaitu membandingkan jumlah laba bersih dengan nilai buku ekuitas. Menurut Robinson dkk (2009) Leverage rasio yang melihat kemampuan perusahaan untuk melunasi hutang jangka panjangnya yaitu bunga dan pokok pinajamannya. Leverage diukur dengan debt to equity ratio pada penelitian ini, yaitu membandingkan jumlah hutang dan ekuitas.

Penelitian ini juga menggunakan variabel kontrol yaitu keuntungan dan kerugian aktuarial. Keuntungan dan kerugian aktuarial adalah perubahan atas nilai kini dari kewajiban imbalan pascakerja sebagai akibat dari perubahan asumsi aktuarial (tingkat diskonto). Perusahaan diberi nilai 1 jika memiliki keuntungan aktuarial dan 0 jika memiliki kerugian aktuarial.

Populasi dalam penelitian ini adalah perusahaan listing dan mempublikasikan laporan keuangan tahunan atau annual report tahun 2014-2016. Sampel dalam penelitian ini adalah seluruh populasi penelitian yang dipilih berdasarkan kriteria sebagai berikut:

a. Terdaftar di BEI pada tahun 2015-2016 dan memiliki data diskonto spesifik

b. Tidak menggunakan mata uang selain rupiah

c. Menggunakan metode koridor pada periode sebelum tahun 2015

d. Memiliki saldo keuntungan/kerugian aktuarial 


\section{ANALISIS DATA DAN PEMBAHASAN}

\section{Deskripsi Sampel Penelitian}

Populasi penelitian ini adalah adalah seluruh perusahaan go public atau perusahaan yang terdaftar di BEI pada tahun 2015-2016. Metode pengambilan sampel menggunakan metode purposive sampling sehingga diperoleh sampel sebanyak 208 perusahaan pertahun dengan rincian pada tabel berikut:

Tabel 1.

Metode Pengambilan Sampel Penelitian

\begin{tabular}{|c|l|c|}
\hline No & \multicolumn{1}{|c|}{ Keterangan } & $\begin{array}{c}\text { Jumlah } \\
\text { Perusahaan }\end{array}$ \\
\hline 1 & $\begin{array}{l}\text { Perusahaan yang terdaftar di Bursa Effek } \\
\text { Indonesia tahun 2016 }\end{array}$ & 538 \\
\hline 2 & $\begin{array}{l}\text { Perusahaan yang tidak menyebutkan tingkat } \\
\text { diskonto secara spesifik }\end{array}$ & 358 \\
\hline 3 & $\begin{array}{l}\text { Perusahaan yang menyebutkan tingkat diskonto } \\
\text { secara spesifik }\end{array}$ & $(150)$ \\
\hline 4 & $\begin{array}{l}\text { Perusahaan yang menggunakan mata uang asing, } \\
\text { menggunakan metode ekuitas, melakukan merger } \\
\text { dan akuisisi, dan tidak memiliki saldo } \\
\text { keuntungan/kerugian aktuarial }\end{array}$ & 208 \\
\hline 4 & Sampel & 416 \\
\hline Jumlah data yang diobservasi (2x208)
\end{tabular}

Sumber: Data yang diolah, 2017

\section{Analisis Deskriptif}

Statistik deskriptif bertujuan untuk mendeskripsikan sebuah data apa adanya dan tidak mengambil kesimpulan secara umum. Analisis deskriptif yang digunakan adalah nilai maksimum, minimum, nilai rata-rata, dan deviasi standar. Hasil statistik deskriptif pada masing-masing variabel digambarkan pada tabel 2:

Tabel 2

Statistik Deskriptif

\begin{tabular}{|l|l|l|l|l|l|l|}
\hline Variabel & Mean & Median & $\begin{array}{l}\text { Maksi } \\
\text { mum }\end{array}$ & $\begin{array}{l}\text { Mini } \\
\text { mum }\end{array}$ & $\begin{array}{l}\text { Deviasi } \\
\text { Standar }\end{array}$ & $\begin{array}{l}\text { Obser } \\
\text { vasi }\end{array}$ \\
\hline DR & 8,63 & 8,59 & 10 & 5 & 0,48 & 416 \\
\hline Aset & 28,77 & 28,72 & 34,58 & 23,56 & 1,96 & 416 \\
\hline ROE & 0,046 & 0,068 & 3,52 & $-11,04$ & 0,625 & 416 \\
\hline DER & 1,97 & 1,032 & 39,48 & $-5,29$ & 3,12 & 416 \\
\hline
\end{tabular}

Sumber: Data yang diolah, 2017

Keterangan: DR: Tingkat Diskonto, Aset: Ukuran Perusahaan, ROE: Profitabilitas, DER: Leverage 
Variabel tingkat diskonto yang diukur dengan nilai tingkat diskonto yang ditetapkan perusahaan memiliki nilai rata-rata (mean) sebesar 8,63 yang berarti bahwa selama tahun 2015-2016 data tingkat diskonto perusahaan sampel berpusat pada nilai 8,63 \%. Nilai tertinggi tingkat diskonto selama tahun 2014-2016 sebesar 10\% dan Nilai terendah tingkat diskonto selama tahun 2015-2016 sebesar $5 \%$. Nilai deviasi standar tingkat diskonto lebih kecil dari nilai rata-rata tingkat diskonto $(0,48<8,63)$, yang menunjukkan bahwa dispersi atau penyebaran data tingkat diskonto berada di sekitar nilai rata-rata (Mason dan Lind, 1996). Hal ini menggambarkan bahwa nilai tingkat diskonto setiap observasi hampir sama dengan nilai rata-ratanya (homogen), tidak ada nilai yang terlalu ekstrim sehingga berbeda jauh dengan nilai rata-rata masing-masing observasi.

Variabel ukuran perusahaan (aset) menunjukkan mean sebesar 28,77 yang berarti bahwa titik keseimbangan data observasi aset terpusat pada nilai 28,77 selama tahun 2015-2016. Nilai aset tertinggi dari perusahaan sampel sebesar 34,58 dan Nilai aset terendah sebesar 23,56. Nilai deviasi standar aset sebesar 1,96 lebih rendah dari nilai mean sebesar 28,77. Hal ini menunjukkan bahwa penyebaran data aset perusahaan sampel berada pada nilai rata-rata sebagaimana data tingkat diskonto sebelumnya yang berarti bahwa setiap data observasi hampir sama dengan nilai rata-ratanya, tidak ada data yang terlalu ekstrim, baik nilai ekstrim yang terlalu tinggi maupun terlalu rendah.

Variabel profitabilitas yang diukur dengan laba bersih (laba setelah pajak) dibagi dengan total ekuitas memiliki nilai rata-rata 0,046 , yang berarti bahwa titik keseimbangan data profitabilitas selama tahun 2015-2016 berada pada nilai 0,046. Perusahaan sampel selama tahun 2015-2016 secara umum dapat memberikan return atau pengembalian kepada pemegang saham sebanyak 4,6\% dari nilai modalnya. Nilai maksimum profitabilitas (ROE) sebesar 3,52 dan Nilai minimum profitabilitas sebesar -11,04. Nilai deviasi standar profitabilitas sebesar 0,625 lebih tinggi dari nilai mean profitabilitas yang hanya sebesar 0,046. Hal ini menunjukkan bahwa penyebaran data profitabilitas berada jauh di atas nilai ratarata. Fenomena ini menggambarkan bahwa data profitabilitas memiliki nilai ekstrim yaitu terlalu tinggi atau terlalu rendah, sehingga nilai rata-rata (mean) berbeda jauh dengan nilai masing-masing data observasi.

Variabel leverage (DER) memiliki nilai mean 1,97 selama tahun 20152016, artinya bahwa titik keseimbangan data leverage selama tahun 2015-2016 berada pada nilai 1,97. Nilai maksimum leverage sebesar 39,48 milik perusahaan Central Proteina Prima, Tbk pada tahun 2016. Dengan nilai leverage tertinggi, perusahaan ini membiayai kegiatan operasionalnya dengan menggunakan hutang atau pinjaman dari kreditur sebesar 39,48 kali dari nilai ekuitasnya. Nilai minimum leverage sebesar -5,29 milik perusahaan Intikeramik Alamasri Industri, Tbk pada tahun 2016. Dengan nilai leverage sebesar $-5,29$ perusahaan ini membiayai kegiatan operasionalnya dengan menggunakan hutang sebesar 5,29 kali dari jumlah ekuitasnya. Nilai leverage pada perusahaan ini bernilai negatif karena nilai ekuitas pada laporan perubahan posisi keuangan bernilai negatif. Nilai deviasi standar leverage pada penelitian ini sebesar 3,01. Nilai ini lebih besar dari 
nilai rata-rata yang hanya bernilai 2,00. Hal ini menggambarkan bahwa penyebaran data leverage berada di atas nilai rata-rata sebagaimana penyebaran data profitabilitas yang berarti bahwa data leverage sangat bervariasi (heterogen), ada nilai yang terlalu tinggi atau terlalu rendah, sehingga nilai mean tidak menggambarkan data observasi sebenarnya.

Variabel dalam penelitian ini memenuhi dalam uji regresi karena telah lolos semua uji asumsi klasik. Besarnya adjusted $R^{2}$ adalah 0,0815 . Nilai ini menggambarkan bahwa hanya $8,15 \%$ variasi variabel ukuran perusahaan (Aset), Profitabilitas (ROE) dan leverage (DER), sebagai variabel independen dapat menjelaskan variasi Tingkat Diskonto sebagai variabel dependen. Sedangkan sisanya sebesar $91,85 \%$ dipengaruhi oleh variabel lain diluar model regresi pada penelitian ini.

Hasil uji $\mathrm{F}$ menunjukan nilai $\mathrm{F}$ sebesar 9,12 dengan probabilitas 0,000. Hasil tersebut menandakan bahwa variabel independen (Ukuran Perusahaan, Profitabilitas, dan Leverage) secara bersama-sama berpengaruh terhadap variabel dependen (Tingkat Diskonto). Hal tersebut dikarenakan tingkat signifikansi variabel yang berada di bawah alpha $1 \%$

Tabel 3

Hasil Uji Hipotesis

\begin{tabular}{|c|c|c|}
\hline Variabel & t-statistik & Probabilitas \\
\hline C & 25,55881 & 0,0000 \\
\hline Aset & $-1,631140$ & 0,1036 \\
\hline ROE & 1,90222 & 0,0569 \\
\hline DER & 1,833860 & 0,0674 \\
\hline ACT & $-5,668637$ & 0,0000 \\
\hline
\end{tabular}

Sumber: Data Sekunder yang diolah,2017

Keterangan: DR: Aset: Ukuran Perusahaan, ROE: Profitabilitas, DER: Leverage, ACT: Keuntungan/kerugian Aktuarial.

Hasil Penelitian pada tabel 3 menunjukan bahwa ukuran perusahaan berpengaruh negatif namun tidak signifikan pada tingkat diskonto. Hal ini membuktikan bahwa perusahaan besar tidak termotivasi untuk menetapkan tingkat diskonto yang rendah untuk menurunkan laba pada saat adopsi metode ekuitas. Hasil penelitian ini tidak sama dengan penelitian Salah dan Smaoui (2014) yang menjelaskan bahwa perusahaan besar menggunakan tingkat diskonto yang lebih rendah. Parker, dkk (2016) menjelaskan ukuran perusahaan berpengaruh negatif dan signifikan pada tingkat diskonto ketika diuji pada perusahaan besar yang berkategori sehat secara keuangan dan tidak signifikan pada perusahaan besar yang berkategori tidak sehat secara keuangan. Dengan demikian dapat disimpulkan bahwa penelitian ini sejalan dengan penelitian Parker, dkk (2016) ketika menguji ukuran perusahaan terhadap tingkat diskonto pada perusahaan yang tidak sehat secara keuangan.

Berdasarkan table 3 pengaruh profitabilitas pada tingkat diskonto memiliki koefisien regresi positif dan signifikan pada alpha $10 \%$ dengan probabilitas 
sebesar 0.0569. Hal ini menunjukkan bahwa perusahaan dengan profitabilitas tinggi menetapkan tingkat diskonto yang tinggi Ketika mengadopsi metode ekuitas. Hasil penelitian ini sejalan dengan hipotesis rencana bonus dalam teori akuntansi positif. Hipotesis rencana bonus menjelaskan bahwa perusahaan yang memiliki rencana bonus akan memilih metode akuntansi yang dapat memindahkan laba periode yang akan datang ke periode saat ini. Bonus berhubungan dengan laba atau profitabilitas, karena besarnya bonus yang diberikan perusahaan tergantung besarnya laba yang diperoleh perusahaan pada periode tersebut.

Hasil penelitian ini tidak sama dengan penelitian Asthana (1999) yang menyatakan bahwa perusahaan dengan profitabilitas tinggi menetapkan tingkat diskonto yang rendah dan perusahaan dengan profitabilitas rendah menggunakan tingkat diskonto yang tinggi. Morais (2010) menjelaskan bahwa perusahaan dengan profitabilitas tinggi dan memiliki keuntungan aktuarial menggunakan metode ekuitas. Dengan asumsi bahwa perusahaan yang memiliki keuntungan aktuarial menggunakan tingkat diskonto yang tinggi, maka dapat disimpulkan bahwa perusahaan dengan profitabilitas tinggi menggunakan tingkat diskonto yang tinggi. Dengan demikian hasil penelitian ini sejalan dengan penelitian yang dilakukan oleh Morais (2010).

Berdasarkan tabel 3 nilai leverage memiliki koefisien positif dan signifikan pada alpha $10 \%$ (nilai $\mathrm{p}=0,0674$ ). Hal ini membuktikan bahwa perusahaan dengan leverage yang tinggi menetapkan tingkat diskonto yang lebih tinggi. Hasil penelitian ini sejalan dengan perjanjian hutang dalam teori akuntansi positif yang menyatakan bahwa perusahaan dengan rasio leverage yang tinggi cenderung menggeser laba periode mendatang ke periode saat ini. Perusahaan berkepentingan pada penurunan leverage untuk memenuhi persyaratan perjanjian hutang. Hasil penelitian ini juga sejalan dengan penelitian Asthana (1999), Salah dan Smaoui (2014) dan Parker (2015) yang menyatakan bahwa perusahaan dengan leverage tinggi secara signifikan menetapkan tingkat diskonto yang tinggi.

\section{KESIMPULAN DAN SARAN}

Merujuk pada hasil analisis data dan pembahasan maka kesimpulan penelitian ini adalah: Ukuran perusahaan tidak berpengaruh pada penetapan tingkat diskonto perusahaan ketika mengadopsi metode ekuitas. Hal ini mengindikasikan bahwa penggunaan metode ekuitas tidak mempengaruhi perusahaan besar dalam menetapkan tingkat diskonto yang lebih tinggi. Profitabilitas dan leverage perusahaan berpengaruh pada penetapan tingkat diskonto perusahaan ketika mengadopsi metode ekuitas. Hal ini mengindikasikan penggunaan metode ekuitas mempengaruhi perusahaan dengan profitabilitas dan leverage tinggi untuk meningkatkan laba atau menurunkan leverage dengan menggunakan tingkat diskonto yang tinggi.

Penelitian ini memiliki keterbatasan penelitian diantaranya perusahaan mungkin menetapkan tingkat diskonto yang lebih tinggi atau lebih rendah dari periode sebelumnya, tetapi tidak bertujuan untuk manipulasi karena nilai tingkat diskonto itu sesuai dengan imbal hasil pasar obligasi korporasi kualitas tinggi atau

* Corresponding author's e-mail: meiabdullah@iaingorontalo.ac.id http://openjournal.unpam.ac.id/index.php/JABI 
obligasi pemerintah. Hal lainnya adalah diterapkannya PSAK 24 (revisi 2015) tidak hanya berkenaan dengan penghapusan metode koridor namun juga penghapusan penggunaan imbal hasil atas aset program, dan pengakuan biaya jasa lalu dalam penghasilan komprehensif sehingga penetapan tingkat diskonto mungkin dipengaruhi oleh faktor-faktor ini.

Atas dasar keterbatasan tersebut, Penelitian selanjutnya mungkin dapat mempertimbangkan variabel lain yang mungkin digunakan perusahaan untuk menaikkan atau menurunkan kewajiban seperti: Imbal hasil atas aset, perbedaan antara tingkat diskonto dan imbal hasil atas aset, tingkat pertumbuhan gaji karyawan (Hsu, 2013) Salah dan Smaoui (2014), dan Asthana (1999). Untuk keakuratan data, peneliti selanjutnya mungkin dapat melakukan wawancara dengan pihak manajemen perusahaan tentang dasar penetapan tingkat diskonto dalam satu periode tertentu, atau kepada pihak-pihak terteuntu yang memiliki kapabilitas dalam permasalahan ini.

\section{DAFTAR PUSTAKA}

Asthana, S. (1999). Determinants of Funding Strategies and Actuarial Choices for Defined-Benefit Pension Plans. Contemporary Accounting Research 16 (1):39-74.

Deegan, C. (2004). Financial Accounting Theory. McGraw-Hill Book Company. Sydney.

Fasshauer, J. D., M. Glaum, dan D. L. Street. (2008). Adoption of IAS 19R by Europe's premier listed companies: Corridor approach versus full recognition. Journal of International Accounting, Auditing and Taxation 17 (2):113-122.

Godwin, J. H., S. R. Golberg, dan J. E. Duchac. (1996). An Empirical Analysis of Factors Associated with Changes in Pension-Plan Interest-Rate Assumptions. Journal Of Accounting, Auditing \& Finance. 305-321

Januarti, I. 2004. Pendekatan Dan Kritik Teori Akuntansi Positif. Akuntansi dan Auditing 1:83-94.

Morais, A. (2010). Actuarial gains dan losses: the determinants of the accounting method. Pacific Accounting Review 22 (1):42-56.

Parker, Swanson dan Dugan. ( 2016). Management of Pension Discount Rate and Financial Health. Journal Of Pasific Economy Policy.

Robinson, T., H. V. Greuning, E. Henry, dan M. A. Braihahn. (2004). International Financial Statement Analysis. Canada: John Wiley \& Shons, INc. 
Riyanto, B. (2008). Dasar-dasar Pembelanjaan Perusahaan. Balai Penerbit Fakultas Ekonomi Universitas Gajah Mada. Yogyakarta

Salah, I. B., dan H. Smaoui. (2014). Determinant of Actuarial Choices for Defined-Benefit Pension Plans: Canadian Evidence. International Review of Business Research Papers 10 (1):192-207.

Suwito, E., dan A. Herawaty. (2005). Analisis Pengaruh Karakteristik Perusahaan Terhadap Tindakan Perataan Laba yang Dilakukan Oleh Perusahaan yang Terdaftar di Bursa Efek Jakarta. Simposium Nasional Akuntansi (SNA) VIII. Solo.

Watts, R. L., dan J. L. Zimmerman. (1978). Toward a Positive Theory of The Determination Of Accounting. The Accounting Review 3:112-132.

Zmijewski, M. E., dan R. L. Hagerman. (1981). An Income Strategy Approach to The Positive Theory Of Accounting Standard Setting/Choice. Accounting and Economic 3:129-149.

Elder.J Randal. et al. (2009). Auditing and Assurance Services. Singapore : Prentice Hall Pearson Education South Asia Ptd Ltd

Garrison H, Ray, Eric W. Noreen and Peter C. Brewer. (2008). Akuntansi Manajerial. Buku 1. Edisi 11. Penerjemah Nuri Hinduan. Jakarta : Salemba Empat 